\title{
UJI PARAMETER STANDAR DAN PENAPISAN FITOKIMIA PADA DAUN STERIL KELAKAI (Stenochlaena palustris (Burm.f.) Bedd.) MENGGUNAKAN EKSTRAKSI BERTINGKAT
}

\author{
Halida Suryadini \\ Program Studi Farmasi, Fakultas MIPA, Universitas Islam Bandung, Jawa Barat, Indonesia \\ email : halidasuryadini89@gmail.com
}

\begin{abstract}
ABSTRAK
Kajian fitokimia dan uji parameter standard telah dilakukan pada daun steril Kelakai (Stenochlaena palustris) yang diperoleh dari daerah Palangkaraya, Kalimantan Tengah. Pada penelitian ini ekstrak diperoleh dengan ekstraksi bertingkat menggunakan metode maserasi N-heksan, etil asetat dan metanol yang digunakan sebagai pelarut. Hasil penetapan parameter standard simplisia daun steril Kelakai diketahui bahwa simplisia berwarna coklat, tidak berbau, berasa kelat, kadar sari larut air $3,34 \%$, kadar sari larut etanol 1,80\%, kadar air 4,71\%, kadar abu total $6 \%$, kadar abu tidak larut asam $1 \%$, kadar susut pengeringan $6 \%$ dan bobot jenis $(\mathrm{g} / \mathrm{g})$ : ekstrak n-heksan 0,94, ekstrak etil asetat 1,41, ekstrak metanol 2,05. Hasil uji fitokimia pada simplisia dan ekstrak daun steril kelakai diduga mengandung senyawa Flavonoid, Tannin dan Fenolik, serta senyawa Flavonoid dan Tannin pada ekstrak etil asetat. Hasil pada aestrak n-heksan negatif terdeteksi.
\end{abstract}

Kata kunci: Daun steril Kelakai (Stenochlaena palustris), uji parameter standard, uji fitokimia, ekstraksi bertingkat

\begin{abstract}
Phytochemical screening test have been carried out from sterile leaves of Kelakai (Stenochlaena palustris), collected from Palangka Raya, Central Borneo. In this study, the extract was collected by multilevel extraction with maceration method, using n-hexane, ethyl acetate and methanol solvent. The result of the determination of parametric standard show that the simplicia are Brown, odorless, tasteless chelate (bitter), the content of water soluble extract is 3,34\%, ethanol soluble extract is $1,80 \%$, water content $4,71 \%$, total ash content $6 \%$, acid insoluble ash content $1 \%$, drying shrinkage simplicia $6 \%$ dan molecul weight $(\mathrm{w} / \mathrm{w})$ : $\mathrm{n}$-hexan extract $0,94 \mathrm{~g} / \mathrm{g}$; ethyl acetate extract $1,41 \mathrm{~g} / \mathrm{g}$; methanol extract 2,05 g/g. Phytochemical tests result on simplicia and methanol extract of Kelakai sterile leaves show contain of Flavonoid, Tannin and Phenolic compounds so in ethyl acetate extract show of Flavonoid and Tannin compounds, and in N-hexan extract secondary metabolite negatif shown.
\end{abstract}

Keyword: Kelakai (Stenochlaena palustris) sterile leaves, phytochemical tests, multilevel extraction, Determination of Parametric standard

\section{PENDAHULUAN}

Kelakai (Gambar 1.) merupakan paku rawa yang tumbuh ke atas, dengan daun fertil yang jumlahnya terbatas, berbentuk menyirip.
Senyawa kimia yang diketahui terkandung dalam Stenochlaena palustris (Darnaedi dan Praptosuwiryo, 2003) meliputi 5-O-acylated flavonol glikosida (stenopalustrosides A-E), Glikosida (stenopaluside) (4S`,5R`)-4-[(9Z)-2, 
13-di-(O- $\beta$-D-glucopyranosyl) $\quad-5, \quad 9, \quad 10-\quad$ Gram positif (Bacillus cereus, Micrococcus trimethyl-8-oxo-9-tetradecene-5-y]\}-3 3, 5- luteus, Staphylococcus aureus dan $S$. trimethylcyclo hexanone, Cerebroside 1-O- $\beta$ - epidermidis) yang signifikan. Konsentrasi D-glucopyranosyl-(2S`,3R',4E,8Z)-2-N[(2R)-hidroxytetracosanoyl] octadecasphinga4, 8-dienine, Kampferols 3-O-(3"-O-E-pcoumaroyl)-(6"-O-E-feruloyl)- $\beta$-Dglucopyranoside, 3-O-(3",6"-di-O-E-pcoumaroyl)- $\beta$-D-glucopyranoside, 3-O-(3"-OE-p-coumaroyl)- $\beta$-D-glucopyranoside, 3-O(6"-O-E-p-coumaroyl)- $\beta$-D-glucopyranoside (tiliroside), 3-O- $\beta$-D-glucopyranoside, 3-oxo4,5-dihydro- $\alpha$-ionyl $\beta$-D-glucopyranoside dan $\beta$-sitosterol-3-O- $\beta$-D-glucopyranoside, $\quad 3$ formyl indole, lutein.

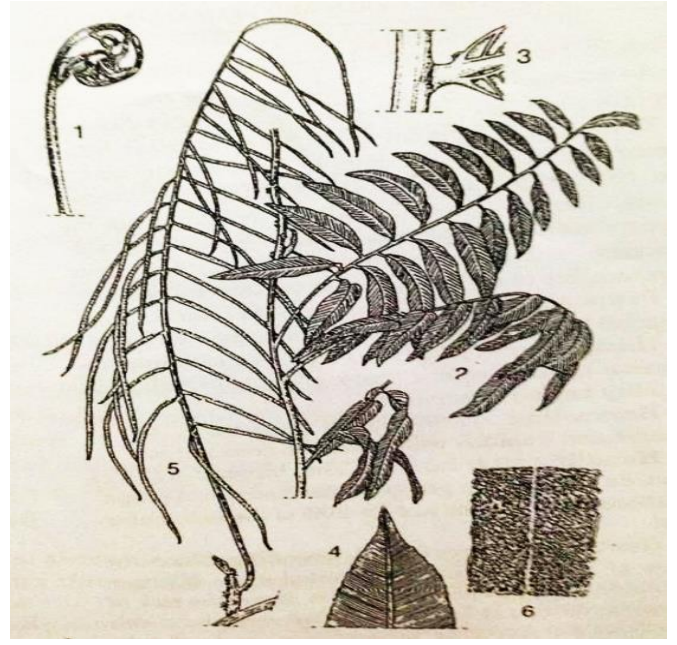

Gambar 1. Stenochlaena palustris (Burm.f.) Bedd. (Darnaedi dan Praptosuwiryo, 2003).

Stenopalustrosides A-D menunjukkan aktifitas antibakteri terhadap strain-strain hambat minimum dari stenoplaustroside A sebesar $2 \mu \mathrm{g} / \mathrm{ml}$, konsentrasi tersebut lebih rendah dari kloramfenicol ( $4 \mu \mathrm{g} / \mathrm{ml})$.Penelitian untuk kandungan alkaloid dari daun $S$. palustris dari daerah Papua Nugini didapat alkaloid-negatif (Darnaedi dan Praptosuwiryo, 2003).

Di Asia Tenggara, daun steril muda yang menggulung dan daun merah yang muda dari S. palustris dinikmati sebagai sayuran. Kelakai mempunyai rasa yang enak, mirip dengan Amaranthus, karena itulah dapat ditemukan dalam menu pada restoran lokal (setempat) dan di Malaysia dikonsumsi seperti bayam. Di Sumatra, sayuran ini dimakan sebagai laksatif. Di Malaysia, tunas muda digunakan untuk mengobati diare dan air rebusan atau jus dari S. palustris digunakan untuk demam. Pada penggunaan luar seduhan S. palustris digunakan sebagai pendingin, diletakkan pada kepala orang yang sedang demam. Di Laos S. palustris juga digunakan untuk melawan demam. Di Thailand jus $S$. palustris digunakan untuk mengobati penyakit kulit dan di Sabah ini digunakan 
sebagai obat bengkak. Di kepulauan Nicobar seluruh bagian dari $S$. palustris digunakan sebagai penggugur kandungan dan untuk kontrasepsi (Darnaedi dan Praptosuwiryo, 2003).

Belum adanya penelitian tentang kajian fitokimia untuk S. palustris yang berasal dari daerah kalimantan tengah membuat penulis melakukan kajian fitokimia dan penetapan parameter standard. Hal ini dilakukan untuk melihat apakah ada perbedaan kualitas $S$. palustris dari setiap daerah.

\section{METODE PENELITIAN}

\subsection{Alat dan Bahan}

Alat penggiling (Blender), alat ukur panjang $(\mathrm{cm})$, alat pemotong, batang pengaduk, batu didih, botol dan penutup botol, cawan penguap, chamber, corong Buchner, corong pisah, eksikator, gelas Erlenmeyer, gelas kimia, gelas ukur, hot plate, kaca objek, kaca penutup, kaca arloji, kertas saring, kondensor, krus silikat, kuvet, labu bersumbat, labu destilasi, labu evaporator, maserator, mikroskop, mikrokapiler, mortar, oven, pipet tetes, penangas air (Memmert), rak tabung reaksi, vacum rotary evaporator (Stuart), spatel, tabung destilasi, tabung reaksi, termometer, timbangan analitik.

Akuades, amil alkohol, ammonia, ammonium nitrat, asam klorida $(\mathrm{HCl}) \mathrm{P}$, asam sulfat encer dan pekat, besi (III) klorida, $\mathrm{CHCl}_{3}$, etanol, eter, etil asetat, $\mathrm{FeCl}_{3}$, gelatin $1 \%, \mathrm{HCl} 2 \mathrm{~N}$, kloralhidrat, kloroform, metanol, $\mathrm{NaOH} 5 \%$, n-heksan, $\mathrm{NH}_{3}$, reagen Mayer, reagen Dragendorff, serbuk magnesium, eter, pereaksi Lieberman-Burchard, toluen, tumbuhan Kelakai.

\subsection{Metode}

Tumbuhan yang digunakan sebagai bahan penelitian ini adalah daun steril Kelakai. Bahan penelitian dalam bentuk simplisia, diperoleh dari Kota Palangkaraya Provinsi Kalimantan Tengah. Determinasi dilakukan di Herbarium Bandungense, Sekolah Ilmu dan Teknologi Hayati, Institut Teknologi Bandung.

\subsubsection{Pemeriksaan Makroskopik dan Organoleptik}

Pengamatan dilakukan terhadap Kelakai segar meliputi karakteristik fisik yakni ukuran dan bentuk fisik bahan, hasil pengamatan kemudian dibandingkan dengan pustaka (WHO, 2011). 
Pengamatan organoleptik dilakukan dengan menggunakan panca indera lima orang responden, untuk mendeskripsikan warna, bau dan rasa dari tumbuhan segar dan simplisia (Depkes, 2000).

\subsubsection{Penetapan Kadar Sari Larut Dalam Air}

Bahan yang telah dikeringkan di udara, dimaserasi selama 24 jam dengan $100 \mathrm{~mL}$ air-kloroform dibiarkan hingga 18 jam, disaring, $20 \mathrm{ml}$ filtrat diuapkan hingga kering dalam cawan penguap yang telah ditara, residu dipanaskan pada suhu $105^{\circ} \mathrm{C}$ hingga bobot tetap. Kadar dalam persen senyawa yang larut dalam air, dihitung dengan rumus (WHO, 2011).

Kadar Sari Larut Air $(\mathrm{g} / \mathrm{g})=$

$\frac{\text { berat sari larut air }}{\text { berat bahan awal }} \times \frac{100}{20} \times 100 \%$

\subsubsection{Penetapan Kadar Sari Larut Dalam Etanol}

Bahan dimaserasi selama 24 jam dengan $100 \mathrm{~mL}$ etanol (95\%) menggunakan labu bersumbat sambil sekali-kali dikocok pada 6 jam pertama dan kemudian dibiarkan selama 18 jam. Kemudian disaring cepat untuk menghindari penguapan etanol (95\%), kemudian $20 \mathrm{ml}$ filtrat diuapkan hingga kering dalam cawan dangkal berdasar rata yang telah ditara, residu dipanaskan pada suhu $105^{\circ} \mathrm{C}$ hingga bobot tetap. Kadar dalam persen senyawa terlarut dalam etanol (95\%) dihitung terhadap ekstrak awal dengan rumus IV.6. (WHO, 2011).

Kadar Sari Etanol $(\mathrm{g} / \mathrm{g})=$

$\frac{\text { berat sari larut etanol }}{\text { berat bahan awal }} \times \frac{100}{20} \times 100 \%$

\subsubsection{Penetapan Kadar Susut Pengeringan}

Bahan dipanaskan pada suhu $105^{\circ} \mathrm{C}$ selama 30 menit. Dihitung berat kadar susut pengeringan dalam g per $g$ terhadap bahan yang telah dikeringkan di udara menggunakan rumus berikut (WHO, 2011):

susut pengeringan

$(\mathrm{g} / \mathrm{g})=\frac{\text { berat awal-berat akhir }}{\text { berat sampel }} \times 100 \%$

\subsubsection{Penetapan Bobot jenis}

Ekstrak cair dimasukkan ke dalam piknometer. Dikurangkan bobot piknometer kosong dari bobot piknometer yang telah diisi. Bobot jenis ekstrak cair 
adalah hasil yang diperoleh dengan membagi bobot ekstrak dengan bobot air, dalam piknometer pada suhu $25^{\circ} \mathrm{C}$ (Depkes, 2000). Bobot jenis ekstrak didapat dari perhitungan menggunakan rumus:

Bobot jenis $=\frac{\mathrm{W} 3-\mathrm{W} 1}{\mathrm{~W} 2-\mathrm{W} 1}$

\subsubsection{Penetapan Kadar abu}

\section{1) Penetapan Kadar Abu Total}

Bahan dipijarkan perlahan-perlahan pada suhu $500-600{ }^{\circ} \mathrm{C}$ hingga berubah menjadi abu yang berwarna putih. Kadar abu total dihitung dalam g per $\mathrm{g}$ terhadap bahan yang telah dikeringkan di udara (WHO, 2011).

\section{2) Penetapan Kadar Abu Tidak Larut Dalam Asam}

Abu yang diperoleh pada penetapan kadar abu total, ditambahkan $\mathrm{HCl}$ 10\% hingga $25 \mathrm{ml}$, ditutup dan didihkan selama 5 menit. Dikumpulkan bagian yang tidak larut dalam asam menggunakan kertas saring bebas abu dan dibilas menggunakan air panas. Kertas saring yang mengandung bahan tidak larut asam dipindahkan ke dalam krus silikat, kemudian dimasukkan ke dalam tanur hingga bobot tetap. Kadar abu tidak larut asam dihitung dengan rumus (WHO, 2011):

$$
\begin{aligned}
& \text { Kadar Abu Tidak Larut Asam (g/g) = } \\
& \frac{\text { Berat abu tidak larut asam }}{\text { Berat simplisia awal }} \text { x } 100 \% \text {...(5) }
\end{aligned}
$$

\subsubsection{Penetapan Kadar air}

Penetapan kadar air dilakukan menggunakan metode destilasi azeotrof. Toluen terlebih dahulu dijenuhkan dengan metode yang terdapat pada Farmakope Indonesia. Sejumlah bahan dan toluen dimasukkan ke dalam labu destilasi kemudian dipanaskan. Penyulingan dilakukan dengan kecepatan kurang lebih 2 tetes per detik, hingga sebagian air tersuling. Volume air dibaca pada skala yang tertera pada alat destilasi. Kadar air dihitung dengan rumus:

Kadar air $=$

$\frac{\text { volume air }(\mathrm{ml}) \times \text { BJ air }(\mathrm{g} / \mathrm{ml})}{\text { berat simplisia awal }(\mathrm{g})} \times 100 \%$...(6)

\subsubsection{Penapisan fitokimia}

Penetapan kandungan metabolit sekunder didalam simplisia dan ekstrak bertingkat 
meliputi Alkaloid, Flavonoid, Kuinon, Saponin, Tanin, Terpenoid, steroid, fenolik, Monoterpen dan Seskuiterpen dilakukan dengan menggunakan metode yang telah dikembangkan oleh fransworth

\subsection{Pembuatan Ekstrak}

Bahan simplisia ditempatkan dalam maserator kemudian ditambahkan pelarut n-heksan dengan perbandingan 3:1 (pelarut simplisia). Dimaserasi selama $3 \mathrm{x}$ 24 jam sambil sesekali diaduk dan dilakukan penggantian pelarut setiap $1 \mathrm{x}$ 24 jam. Hasil filtrat ditampung pada wadah penampung (A). Ampas kemudian ditambahkan dengan pelarut etil asetat dengan perbandingan 3:1 (pelarut simplisia), dilakukan prosedur maserasi seperti pada ekstraksi dengan n-heksan. Hasil filtrat ditampung pada wadah penampung (B). Ampas ekstraksi dengan etil asetat di maserasi dengan metanol dan filtrat ditampung pada wadah penampung (C). Ketiga ekstrak (ekstrak n-heksan, etil asetat, dan metanol) yang telah ditampung selanjutnya dipekatkan dengan rotary vacuum evaporator tekanan rendah pada suhu tidak lebih dari $70^{\circ} \mathrm{C}$ (Depkes,
2000:10). Rendemen dihitung menggunakan rumus :

Rendemen ekstrak $(\mathrm{g} / \mathrm{g})=$

$\frac{\text { berat ekstrak pekat }}{\text { berat simplisia uji }} \times 100 \%$

\section{HASIL DAN PEMBAHASAN}

3.1 Pengamatan Mikroskopik

Pengamatan Mikroskopik serbuk simplisia daun steril Kelakai menunjukkan adanya fragmen berkas pembuluh (trakeid), dan stomata tipe diastitik yang dapat dilihat pada Gambar: 2, 3. Hasil pengamatan sesuai dengan pustaka (Bracegirdle dan Miles, 1971; Hidayat, 1995).

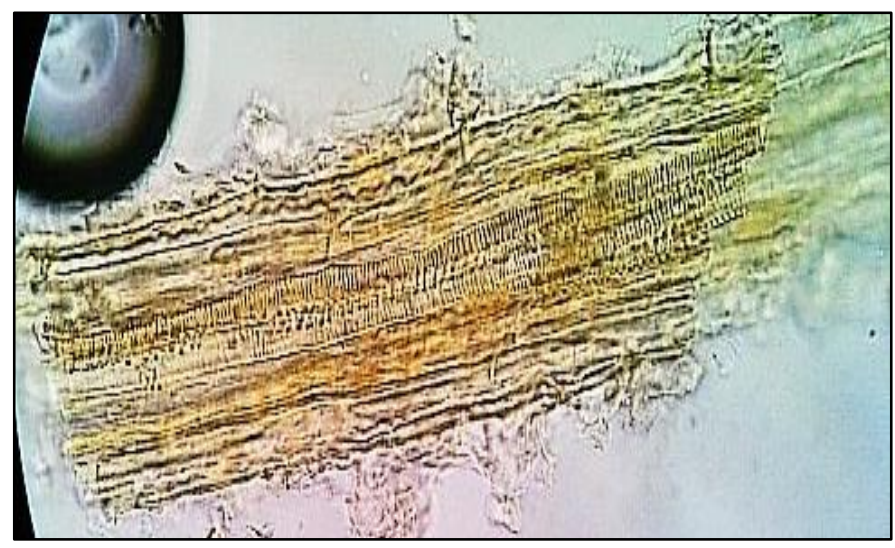

Gambar.2 Mikroskopik serbuk simplisia daun steril Kelakai : Fragmen trakeid. 


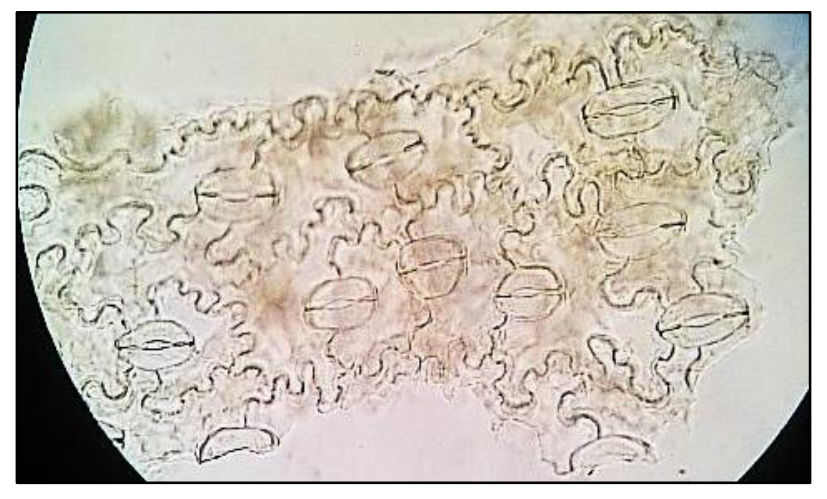

Gambar.3 Mikroskopik serbuk simplisia daun steril Kelakai: fragmen stomata.

\subsection{Penetapan Parameter Mutu Ekstrak}

Pada penelitian ini metode ekstraksi yang digunakan adalah maserasi bertingkat menggunakan tiga jenis pelarut yang memiliki tingkat kepolaran yang berbeda. Pelarut yang digunakan adalah n-heksan yang mewakili jenis pelarut yang nonpolar, etil asetat mewakili pelarut yang bersifat semi polar dan metanol untuk jenis pelarut yang bersifat polar. Masing-masing pelarut digunakan dalam jumlah 10 liter. Penggunaan maserasi sebagai metode ekstraksi dipilih karena maserasi adalah proses ekstraksi tanpa menggunakan panas. Tidak digunakannya suhu dalam penelitian ini untuk melihat kinerja pelarut secara maksimal tanpa adanya faktor lain. Diperoleh 3 ekstrak yakni ekstrak n-heksan, ekstrak etil asetat, dan ekstrak metanol yang kemudian ketiganya dipekatkan menggunakan vacuum rotary evaporator sehingga diperoleh ekstrak pekat. Hasil perolehan rendemen ekstrak N-heksan sebanyak 0,91 \% (g/g), Etil asetat 1,23\% $(\mathrm{g} / \mathrm{g})$, dan metanol 10,72 \% (g/g). Hasil ekstraksi menunjukkan bahwa ekstrak metanol memiliki nilai rendemen tertingggi yakni sebesar 10,72 \%. Rendemen metanol tertinggi karena $S$. Palustris banyak mengandung senyawa polar seperti glukosida. Fungsi dari penetapan parameter standard untuk menjamin kualitas dari simplisia atau ekstrak.. Senyawa larut air lebih banyak larut dibanding senyawa larut etanol karena $S$. palustris banyak mengandung senyawa polar seperti glikosida atau karbohidrat.

\subsubsection{Kadar Sari}

Parameter kadar sari digunakan untuk mengetahui jumlah kandungan senyawa kimia dalam sari simplisia. Parameter kadar sari dalam pelarut tertentu ditetapkan sebagai parameter uji bahan baku obat tradisional karena jumlah kandungan senyawa kimia dalam sari simplisia akan berkaitan erat dengan reproduksibilitasnya dalam aktivitas 
farmakodinamik simplisia tersebut (Depkes RI, 1995). Parameter kadar sari dalam pelarut tertentu dilakukan dengan menggunakan pelarut air dan etanol.

Hasil penetapan kadar sari larut air daun steril Kalakai sebesar 3,34\%. Kadar sari larut air memberikan gambaran awal jumlah senyawa kandungan dalam simplisia yang dapat larut oleh air atau oleh pelarut yang bersifat polar (Depkes RI, 2000). menunjukkan kadar sari larut air simplisia

Tabel 1. Perhitungan penetapan kadar sari larut air.

\begin{tabular}{|c|c|c|c|c|c|c|c|c|}
\hline \multirow[b]{2}{*}{ No } & \multicolumn{4}{|c|}{ Berat (gram) } & \multicolumn{2}{|c|}{ Berat (gram) } & \multirow{2}{*}{$\begin{array}{c}\text { Kadar Sari } \\
(\mathrm{g} / \mathrm{g})\end{array}$} & \multirow{2}{*}{$\begin{array}{c}\text { rata- } \\
\operatorname{rata}(g / g)\end{array}$} \\
\hline & $\begin{array}{c}60 \\
\text { Menit }\end{array}$ & $\begin{array}{c}120 \\
\text { Menit }\end{array}$ & $\begin{array}{c}180 \\
\text { Menit }\end{array}$ & $\begin{array}{c}240 \\
\text { Menit }\end{array}$ & $\begin{array}{l}\text { Cawan } \\
\text { kosong }\end{array}$ & $\begin{array}{c}\text { Berat sari } \\
\text { larut air }\end{array}$ & & \\
\hline 1 & 64,62 & 64,62 & 64,60 & 64,60 & 64,45 & 0,15 & $15 \%$ & \multirow{2}{*}{$13,5 \%$} \\
\hline 2 & 120,30 & 120,30 & 120,29 & 120,28 & 120,16 & 0,112 & $12 \%$ & \\
\hline
\end{tabular}

Nilai kadar sari larut etanol yang polar dibanding air. Hasil penetapan kadar diperoleh dari hasil penetapan kadar sari larut sari larut air dan pelarut etanol etanol simplisia daun steril Kalakai adalah mengindikasikan bahwa senyawa yang sebesar 1,80 \%. Nilai ini memberikan bersifat polar lebih banyak terkandung dalam gambaran awal jumlah senyawa kandungan simplisia daun steril Kalakai dibandingkan dari simplisia daun steril Kalakai yang dapat senyawa yang bersifat kurang polar. larut dalam etanol atau pelarut yang kurang

Tabel 2. Perhitungan Penetapan kadar sari larut etanol.

\begin{tabular}{|c|c|c|c|c|c|c|c|c|}
\hline \multirow[b]{2}{*}{ No } & \multicolumn{4}{|c|}{ Berat (gram) } & \multicolumn{2}{|c|}{ Berat (gram) } & \multirow{2}{*}{$\begin{array}{c}\text { Kadar } \\
\text { Sari } \\
(\mathbf{g} / \mathbf{g})\end{array}$} & \multirow[b]{2}{*}{$\begin{array}{c}\text { rata-rata } \\
(\mathrm{g} / \mathrm{g})\end{array}$} \\
\hline & $\begin{array}{c}60 \\
\text { Menit }\end{array}$ & $\begin{array}{c}120 \\
\text { Menit }\end{array}$ & $\begin{array}{c}180 \\
\text { Menit }\end{array}$ & $\begin{array}{c}240 \\
\text { Menit }\end{array}$ & $\begin{array}{l}\text { Cawan } \\
\text { kosong }\end{array}$ & $\begin{array}{c}\text { Berat sari larut } \\
\text { etanol }\end{array}$ & & \\
\hline 1 & 61,83 & 61,82 & 61,82 & 61,82 & 61,74 & 0,08 & $8 \%$ & \multirow[b]{2}{*}{$7,5 \%$} \\
\hline 2 & 65,52 & 65,52 & 65,51 & 65,51 & 65,44 & 0,07 & $7 \%$ & \\
\hline
\end{tabular}

3.2.2 Susut Pengeringan, Bobot Jenis, Kadar Abu dan Kadar Air

Penetapan kadar susut pengeringan bertujuan untuk memberikan batasan maksimal besarnya senyawa yang hilang pada proses pengeringan (Depkes RI, 2000:13). Hasil penetapan kadar susut pengeringan daun steril Kelakai diperoleh nilai sebesar $6 \%(\mathrm{~g} / \mathrm{g})$. 
Tabel 3. Perhitungan kadar susut pengeringan.

\begin{tabular}{|c|c|c|c|c|c|}
\hline \multirow{2}{*}{ No. } & \multicolumn{3}{|c|}{ Berat (gram) } & \multirow{2}{*}{$\begin{array}{c}\text { Susut } \\
\text { Pengeringan } \\
(\mathbf{g} / \mathbf{g})\end{array}$} & $\begin{array}{c}\text { Rata-rata } \\
(\mathbf{g} / \mathbf{g})\end{array}$ \\
\cline { 2 - 4 } & Simplisia & $\begin{array}{c}\text { Cawan } \\
\text { kosong }\end{array}$ & $\begin{array}{c}\text { Cawan setelah } \\
\text { pengeringan }\end{array}$ & $\begin{array}{c}7 \% \\
6\end{array}$ \\
\hline 1 & 2,00 & 36,12 & 37,98 & $5 \%$ & $6 \%$ \\
\hline 2 & 2,00 & 36,63 & 38,53 & $5 \%$ & \\
\hline
\end{tabular}

Penetapan kadar bobot jenis bertujuan bobot jenis memberikan gambaran kandungan untuk memberikan batasan tentang besarnya kimia terlarut (Depkes, 2000 : 14), maka dari masa per satuan volume yang merupakan hasil penetapan bobot jenis diketahui bahwa parameter khusus ekstrak cair sampai ekstrak kandungan terbesar kimia terlarut terdapat pekat (kental) yang masih dapat dituang pada ekstrak metanol. Bobot jenis ekstrak (Depkes RI, 2000: 13), dan diperoleh hasil merupakan hasil perhitungan antara berat bobot jenis ekstrak n-heksan sebesar 0,94 g/g, ekstrak dan berat $1 \mathrm{~mL}$ air.

etil asetat $1,41 \mathrm{~g} / \mathrm{g}$ dan metanol $2,05 \mathrm{~g} / \mathrm{g}$. Nilai

Tabel 4. Perhitungan bobot jenis ekstrak.

\begin{tabular}{|c|c|c|c|c|}
\hline \multirow[b]{2}{*}{ Ekstrak } & \multicolumn{3}{|c|}{ Bobot Penimbangan (g) } & \multirow[b]{2}{*}{$\begin{array}{c}\text { Bobot } \\
\text { Jenis }\end{array}$} \\
\hline & $\begin{array}{l}\text { Kosong } \\
\text { (W1) }\end{array}$ & $\begin{array}{c}\text { Berisi aquadest } \\
\text { (W2) }\end{array}$ & $\begin{array}{c}\text { Berisi ekstrak } \\
\text { (W3) }\end{array}$ & \\
\hline N-heksan & \multirow{3}{*}{9,56} & \multirow{3}{*}{10,71} & 10,68 & 0,94 \\
\hline etil ase & & & 11,17 & 1,41 \\
\hline Metanol & & & 11,92 & 2,05 \\
\hline
\end{tabular}

Nilai dari penetapan kadar abu berguna sebagai parameter rentang kandungan mineral internal dan eksternal yang diperbolehkan ada, hal ini terkait dengan kemurnian dan kontaminasi (Depkes RI, 2000: 18). Penetapan kadar abu yang dilakukan yakni kadar abu total dan kadar abu tidak larut asam. Kadar abu total simplisia daun steril Kelakai dalam penelitian ini adalah 6,095\% (Tabel 5). Nilai Kadar abu total menunjukkan kandungan senyawa anorganik yang didapat dari tumbuhan Kelakai atau diperoleh dari luar tumbuhan. 
Tabel 5. Perhitungan penetapan kadar abu total.

\begin{tabular}{|c|c|c|c|c|c|}
\hline \multirow[b]{2}{*}{ No. } & \multicolumn{3}{|c|}{ Berat (gram) } & \multirow{2}{*}{$\begin{array}{l}\text { Kadar } \\
\text { abu } \\
\text { total } \\
(\mathrm{g} / \mathrm{g})\end{array}$} & \multirow{2}{*}{$\begin{array}{c}\text { Rata- } \\
\text { rata } \\
(\mathrm{g} / \mathrm{g})\end{array}$} \\
\hline & Simplisia & $\begin{array}{c}\text { Krus } \\
\text { kosong }\end{array}$ & $\begin{array}{c}\text { Krus berisi } \\
\quad \text { abu }\end{array}$ & & \\
\hline 1 & 2,00 & 37,70 & 37,82 & $6 \%$ & \multirow{2}{*}{$6 \%$} \\
\hline 2 & 2,00 & 36,73 & 36,85 & $6 \%$ & \\
\hline
\end{tabular}

Abu yang didapat dari penetapan kadar abu klorida $10 \%$. Hasil penetapan kadar abu total selanjutnya digunakan untuk penetapan tidak tidak larut asam simplisia Kalakai kadar abu tidak larut asam. Asam yang adalah 1,61\%. Tabel 6. Perhitungan digunakan untuk melarutkan abu adalah asam penetapan kadar abu tidak larut asam.

\begin{tabular}{|c|c|c|c|c|c|}
\hline \multirow{2}{*}{ No. } & \multicolumn{3}{|c|}{ Berat (gram) } & \multirow{2}{*}{$\begin{array}{c}\text { Kadar abu } \\
\text { tidak larut asam } \\
(\mathrm{g} / \mathrm{g})\end{array}$} & \multirow[b]{2}{*}{$\begin{array}{c}\text { rata-rata } \\
\quad(\mathrm{g} / \mathrm{g})\end{array}$} \\
\hline & Simplisia & $\begin{array}{c}\text { krus } \\
\text { kosong }\end{array}$ & $\begin{array}{c}\text { krus }+ \text { abu } \\
\text { tidak larut asam }\end{array}$ & & \\
\hline 1 & 2,00 & 37,70 & 37,71 & $0,5 \%$ & \multirow{2}{*}{$1 \%$} \\
\hline 2 & 2,00 & 36,73 & 36,76 & $1,5 \%$ & \\
\hline
\end{tabular}

Penetapan kadar air berfungsi sebagai batasan minimal kandungan air pada simplisia (Depkes RI, 2000). Nilai kadar air simplisia daun steril Kalakai pada penelitian ini adalah 4,51 \%, hasil ini dianggap memenuhi persyaratan kadar air simplisia (daun), yakni kurang dari 5\% (Agoes, 2009).

Tabel 7. Penetapan kadar air

\begin{tabular}{|c|c|c|c|}
\hline no. & $\begin{array}{c}\text { Berat } \\
\text { simplisia } \\
\text { (gram) }\end{array}$ & $\begin{array}{c}\text { Volume } \\
\text { air (ml) }\end{array}$ & $\begin{array}{c}\text { kadar } \\
\text { air } \\
\text { (g/mL) }\end{array}$ \\
\hline 1 & 17,5 & 0,79 & 4,51 \\
\hline 2 & 17,3 & 0,85 & 4,91 \\
\hline
\end{tabular}

\subsubsection{Penapisan Fitokimia}

Penapisan fitokimia dalam penelitian ini dilakukan terhadap simplisia dan ekstrak Kalakai. Hasil penapisan fitokimia dapat dilihat pada Tabel 9. Hasil penapisan fitokimia simplisia daun steril Kalakai mengindikasikan bahwa simplisia mengandung senyawa flavonoid, polifenol, tannin dan tidak terdeteksi adanya kandungan senyawa alkaloid, hal ini sesuai dengan pustaka (Darnaedi, 2003: 187). Hasil penapisan ekstrak diduga pada ekstrak etil asetat terdeteksi adanya kandungan senyawa flavonoid dan tannin, pada ekstrak metanol terkandung senyawa flavonoid, polifenolat, 
tanin dan pada ekstrak n-heksan tidak penapisan fitokimia. terkandung senyawa yang diujikan pada

Tabel 8. Hasil penapisan fitokimia simplisia dan ekstrak daun steril Kalakai.

\begin{tabular}{|c|c|c|c|c|}
\hline \multirow{2}{*}{ Golongan senyawa } & \multicolumn{4}{|c|}{ Hasil penapisan } \\
\cline { 2 - 5 } & Simplisia & $\begin{array}{c}\text { Ekstrak } \\
\text { N-heksan }\end{array}$ & $\begin{array}{c}\text { Ekstrak } \\
\text { etilasetat }\end{array}$ & $\begin{array}{c}\text { Ekstrak } \\
\text { Metanol }\end{array}$ \\
\hline Alkaloid & - & - & - & - \\
\hline Flavonoid & + & - & + & + \\
\hline Kuinon & - & - & - & - \\
\hline Saponin & - & - & - & + \\
\hline Tanin & + & - & + & + \\
\hline Fenolik & + & - & - & - \\
\hline Terpenoid & - & - & - & - \\
\hline Steroid & - & - & - & - \\
\hline $\begin{array}{c}\text { Monoterpen dan } \\
\text { Seskuiterpen }\end{array}$ & - & - & - & \\
\hline
\end{tabular}

Keterangan:

$+=$ terdeteksi

- = tidak terdeteksi

\section{KESIMPULAN DAN SARAN}

\subsection{Kesimpulan}

Hasil uji fitokimia pada simplisia dan ekstrak daun steril kelakai diduga mengandung senyawa Flavonoid, Tannin dan Fenolik pada ekstrak metanol serta senyawa Flavonoid dan Tannin pada Ekstrak Etil Asetat. Hasil pada ekstrak n-heksan negatif terdeteksi. Hasil penetapan parameter standard adalah Hasil uji parameter standard pada simplisia yakni uji organoleptik berwarna coklat tua, tidak berbau dan rasa kelat, kadar sari larut air 3,34 \%, kadar sari larut etanol $1,80 \%$, kadar air 4,71\%, kadar abu total $6 \%$, kadar abu tidak larut asam $1 \%$, kadar susut pengeringan $6 \%$, bobot jenis ekstrak n-heksan $0,94(\mathrm{~g} / \mathrm{g})$, etil asetat $1,41(\mathrm{~g} / \mathrm{g})$ dan metanol $2,05(\mathrm{~g} / \mathrm{g})$.

\subsection{Saran}

Disarankan melakukan penelitian lanjutan Kalakai untuk menentukan kinerja terbaik pelarut antara etil asetat dan methanol 
dengan penentuan kadar flavonoid total dalam setiap ekstrak untuk melengkapi data ilmiah mengenai Kalakai sebagai tumbuhan obat.

\section{DAFTAR PUSTAKA}

Agoes G., 2009. Teknologi Bahan Alam serial farmasi industri-2 edisi revisi, Penerbit ITB, Bandung.

Azis, S., 2014. Senyawa Alam Metabolit Sekunder Teori, Konsep, dan Teknik Pemurnian edisi 1, Cetakan 1,Deepublish, Yogyakarta.

Bracegirdle, B., dan Miles, PH., 1971. An Atlas of Plant Structure. Volume 1. Butler \& Tanner Ltd, London.

Chai TT., Panirchellvum E., Ong H., dan Wong F., 2012. Phenolic Contents and Antioxidant Properties of Stenochlaena palustris, an edible Medicinal Fern. Botanical Studies, 53: 439-446.

Darnaedi D., dan Praptosuwiryo, TN.,2003. Stenochlaena palustris (Burm.f.) Bedd. In: de Winter, W.P dan Amoroso. V.B (Editors): Plant Resources Of SouthEast Asia 15 (2), Cryptogams: Fren and fern allies. Prosea Foundation, Bogor, Indonesia. pp 186-188.

Depkes, 1977. Materia Medika Indonesia, jilid I, Direktorat Jendral Pengawasan Obat dan Makanan, Jakarta.

Depkes, 1989. Materia Medika Indonesia, jilid V, Direktorat Jendral Pengawasan Obat dan Makanan, Jakarta.

Depkes, 1995. Farmakope Indonesia, edisi IV, Direktorat Jendral Pengawasan Obat dan Makanan, Jakarta.

Depkes, 2000. Parameter Standard Umum Ekstrak Tumbuhan Obat, cetakan pertama, Direktorat Jendral Pengawasan Obat dan Makanan, Jakarta. de Winter WP dan Amoroso VB (Editors): Introduction Plant Resources Of SouthEast Asia 15 (2), Cryptogams: Fern and fern allies. Prosea Foundation, Bogor, Indonesia. pp 13-46

Farnsworth NR., 1966. Biological and Phytochemical Screening of Plants, Journal of Pharmaceutical Science 55(3) : 225-269.

Harborne JB., 1987. Metode Fitokimia, Penuntun Cara Modern Menganalisis Tumbuhan., terbitan kedua, Terjemahan Padmawinata, K., Penerbit ITB, Bandung.

Heinrich M., Barnes J., Gibbons S., dan Williamson EM., 2009. Farmakognosi dan Fitoterapi, terjemahan Winny, R.S., Penerbit EGC, Jakarta.

Hidayat EB., 1995. Anatomi Tumbuhan Berbiji; Penerbit ITB, Bandung.

Lenny S., 2006. Isolasi dan Uji Bioaktifitas Kandungan Kimia Utama Puding Merah dengan Metode Uji Brine Shrimp, USU repository®.

Markham KR., 1988. Cara mengidentifikasi flavonoid. Terjemahan Padmawinata, K., Penerbit ITB, Bandung.

Robinson T.,1995. Kandungan Organik Tumbuhan Tinggi. Terjemahan . Padmawinata, K., Penerbit ITB, Bandung

The Plant list, a working list of all plant species, Stenochlaena palustris (Burm. F.) Bedd, 2010. original publication detail: Ferns Brit. India (Suppl.): 26, $t$. 20126 1876., http://www.theplantlist.org Tropicos®., 2014. Stenochlaena palustris (Burm.f.) Bedd., Tropicos.org. Missouri Botanical Garden, Missouri.

WHO (World Health Organization), 2011. Quality control methods for herbal materials. Malta, Switzerland 